\title{
BIBLE STUDY WITHIN ESTABLISHED BIBLE STUDY GROUPS: RESULTS OF AN EMPIRICAL RESEARCH PROJECT
}

\author{
Ernst M Conradie \\ Department of Religion and Theology \\ University of the Western Cape, \\ Louis C Jonker \\ Department of Old and New Testament \\ Stellenbosch University
}

\section{Introduction}

The purpose of this contribution is to discuss the results of the empirical research project on Biblical interpretation within the context of established Bible study groups that was launched in 1999. ${ }^{1}$ The scope of this project remained limited. The purpose of the project was to investigate the validity of a number of hypotheses on various factors that play a role in Biblical interpretation in a group context.

These hypotheses were derived from the evidence gathered during the pilot phase of the larger project. These hypotheses were formulated by us (Conradie and Jonker) on behalf of the research team but did not necessarily express the views of the whole research team. They therefore articulate our impressions of the factors that play a role in group Bible study, derived from the empirical evidence accumulated from all the Bible studies investigated during the pilot project over a period of three years. The purpose of these hypotheses was not to try to establish whether these factors play a role, but to articulate in what way they influence group Bible study and how they do so in relation to one another.

In the first part of this contribution these hypotheses are discussed on the basis of the thick descriptions of the various Bible study events as documented elsewhere in this volume. The second part of this contribution reflects briefly on the significance of such results. It also raises a number of new questions that emerged during this research project and that may require further research. In order to generate new hypotheses it suggests a way forward in this regard.

\section{Testing the hypotheses}

In the chronicle of a regional research project elsewhere in this volume detail was provided on the hypotheses and on the procedures that were established in order to investigate these hypotheses. Let us now reflect on these hypotheses one by one in terms of the data gathered through the empirical research.

2.1 The role of doctrinal keys within a particular ecclesial tradition of interpretation

The following hypothesis was stated on this aspect:

1. See the "Chronicle on a regional research project" elsewhere in this volume for detail on this project. 
The interpretation and application of Biblical texts within a given contemporary context is strongly influenced by the dominant doctrinal keys ${ }^{2}$ of the group. These doctrinal keys are derived from the ecclesial or theological tradition of the group. Most groups show a strong need for a confirmation and reassurance of the legitimacy of their doctrinal keys.

The research project confirmed the impressions of the pilot project that ecclesial tradition is $a$, and perhaps the dominant factor that influences Biblical interpretation, especially within the context of established Bible study groups. These doctrinal keys shape whatever the group would expect to find in the Bible. This is especially significant where soteriological motifs operate as doctrinal keys. If the group understands the gospel as a message about forgiveness of sins (the so-called juridical theory of salvation, focusing on the symbol of the cross), it will find that message in the text and the group discussion will steer willy-nilly in that direction. Likewise, if the group understands the gospel as a message of the power of the Holy Spirit to heal the sick, to conquer evil, to drive out demons, to rescue those who are in danger, to save those who are entangled by sin (the socalled classic theory of salvation, focusing on the symbol of the resurrection), this message will be discovered in the text. Alternatively, where the message of liberation theology has been heard, the gospel may be understood as liberation from poverty and oppression. Finally, some also interpret the gospel in terms of the so-called liberal theory of salvation (focusing on the symbol of the incarnation), i.e. as the inspiring example set by Jesus Christ, the prophets and the apostles that we are called to follow, also in difficult circumstances.

In the pilot study the influence of such doctrinal keys was particularly evident in the different interpretations of Mark 2:1-12. Some groups put the emphasis on God's power as illustrated in the healing miracle, many focused on the forgiveness of sins instead while others emphasised the example of support set by the lame man's friends. The influence of different soteriological motifs was therefore quite obvious in the interpretation of this text. Bible study groups from a reformed or evangelical background tended to favour the motif of the forgiveness of sins. By contrast, groups with a Pentecostal orientation tended to focus on the theme of healing. One student group from a Pentecostal church (where several group members came from a reformed background) allowed for the motif of healing but within the larger framework of the forgiveness of sins.

In the main project the influence of such doctrinal keys was perhaps somewhat less evident than what was anticipated. Nevertheless, a number of classic Christian doctrines continued to shape the readings of the various groups:

- One of the key concepts in the readings of the Dutch Reformed Church' Ottery group is to have faith in Jesus. This is expressed as a simple trust in Jesus. One has to believe in Jesus without seeing him, even if he does no miracles. This requires an acceptance of his authority as the Son of God (the influence of Nicene Christology on the group is obvious here). If we trust in Jesus, we would not have to face the disastrous consequence that the rejection of Jesus (e.g. by the people of Nazareth, Matthew 13)

2. Doctrinal keys are typically based on the dominant beliefs, doctrines, values, customs, and habits of interpretive communities. They are not directly derived from either the Biblical text or the contemporary world but are precisely the product of previous attempts to construct a relationship between text, tradition and context. They have a double function in theological interpretation. They provide a key to unlock both the meaning of the contemporary context and of the Biblical texts. They therefore (and simultaneously) enable an interpreter to establish a link between text and contemporary context. Doctrinal keys are not only employed to find similarities but to construct similarities, to make things similar (idem-facere), if necessary. The scope of such doctrinal keys is often quite comprehensive: they purport to provide a clue to the core meaning of the contemporary context as a whole and the Biblical text as a whole. 
may entail. Being with Jesus is therefore crucial. The Bible study on Luke 4 reinforced the group's convictions about "God's great love for sinners", for ordinary poor, sinful people (such as themselves). In both readings traces of the doctrine of providence may be found: the reassurance that God / Jesus cares for us whatever our circumstances may be. We should therefore put our trust and faith in Jesus only.

- Christological convictions also played a vital role in the two readings of the Sokhanya group. They focused on Jesus and his divine identity and the failure of the people of Nazareth to recognise that. As the Son of God, Jesus had the power to do miracles (Matt 13:54, 58), to heal and to liberate (Luke 4:19). In terms of the African worldview that the group shares, the concrete reality of healing wonders, both in the Bible and today's world, is taken for granted.

- The Langa Baptist group assumed the necessity of faith in God and in Jesus Christ as the Son of God in both their Bible studies. While the people of Nazareth rejected Jesus, we should hold unto our faith in Jesus. Although the group enthusiastically affirmed the rhetoric of liberation from oppression, colonialism, racism and apartheid in the Bible study on Luke 4, the discussion actually focused on the need to exercise financial responsibility in order to counter a spirit of greediness and being "shopaholics". Such a sense of responsibility is only possible through a life of faith, i.e., when your orientation to life as a whole is appropriate. In both cases the group's doctrinal key (faith in Jesus) provided the group with a way to make sense of the text.

- The somewhat dysfunctional nature of the Strand Anglican group made it difficult to assess the influence of doctrinal keys on this group.

- The influence of particular doctrinal keys in the Belhar Anglican group is less prominent. Perhaps this is not surprising given the somewhat amorphous doctrinal heritage of the Anglican tradition. Nevertheless, the group repeatedly stressed the importance of faith in Jesus. People should believe and have faith in God / Jesus and they will receive blessings. This emphasis correlates well with the nature of this group as a spiritual and social support group. Although the power of healing was recognised, it is significant that the reference to "the poor" is spiritualised by equating it with a lack of faith and not of material possessions.

- The role of doctrinal keys in the readings of the Lighthouse group is complex. The discourse of the group and especially the group leader is heavily laden with doctrinal affirmations. His mini-lectures serve the purpose of a re-affirmation and even indoctrination of the full range of evangelical truths that he espouses. He ensures that the interpretations of the text and the group discussion stay within the parameters of such evangelical doctrines. Moreover, in the second reading on Luke, his mini-lecturers guard against the "wrong" interpretation of the text by liberation theology. For him, this was necessary because this particular group received input from the research team on the way in which the text is understood in liberation theology (as one tradition of interpretation). His mini-lecturers clearly attempted to reinforce the group's own identity, beliefs and commitments. This illustrated the power of ecclesial traditions and of doctrinal keys to shape the reading of the text.

Although the group leader's doctrinal keys are easily articulated it is not so easy to describe the doctrinal keys of the group as a whole. One may assume that the group members came from different ecclesial backgrounds before they joined the Lighthouse church. The group members therefore draw from the doctrinal keys of various church traditions. In his thick description of this group's Bible studies, Lawrie concludes that 
contextual factors (i.e. that of the lower middleclass) played at least as important a role as ecclesial tradition(s) did.

The evidence from this research project therefore indicates that most established Bible study groups do show a strong need for a confirmation and reassurance of the legitimacy of their doctrinal keys.

\subsection{The role of interpretative strategies used towards application}

a) The following hypothesis was stated on this aspect in the research proposal:

Various strategies may be used for a relatively direct application of a text, for example:

- The identification of a-temporal doctrinal or moral rules in the text ("We must remember that ..."; "I learned today that ...");

- The identification of inspiring analogies between the situation described in the text and the group's own context ("I also experience ... in my life.");

- The search for a contemporary fulfilment of God's promises embedded in the text (God is encouraging / challenging / warning / reassuring me that ...);

- The search for a confirmation of the beliefs, values and practices of the group in the text (by quoting proof texts).

Furthermore, the events within which the reading of a Biblical text are embedded (where the interpretation / application arrived at through the Bible Study is presumably expressed) are strongly influenced by the specific purpose for which the Bible Study group meets regularly (e.g. a support group, spiritual growth through an integration of faith commitments, a deepening of knowledge and insight, encouragement for service, an opportunity for worship and experiencing God's presence), and only indirectly by the reading of the text itself.

b) The use of these interpretative and applicative strategies (often in association with one another) was evident in many of the Bible study events. The following examples may illustrate the point:

- The Sokhanya group members identified themselves with the position in which Jesus found himself (as described in Matt 13:53-58). As religious leaders, they experience similar suspicion and rejection from their local communities. The group subsequently explained the significance of the text for themselves in terms of the example of Jesus who showed strength of character to respond to such a predicament in which religious leaders find themselves. The text gives them the power to confront similar situations.

- The dominant interpretative strategy of the Belhar group was quite similar. Their experience of not being respected by their own family or immediate context resonates with the lack of recognition that Jesus experienced in his hometown. In the same way that Jesus, the prophet, was criticised by his own people, so modern church leaders suffer from lack of respect and recognition by their own congregations. There was a prevailing awareness of themselves as people who also suffer from a lack of recognition, as was the case with Jesus in Nazareth.

- The Lighthouse group concurred: The people of Nazareth took offence at Jesus, because they knew him as an ordinary member of the community and could not accept him in a new role. What Jesus suffered, we shall also suffer as Christians: "There will be 'offence' in your life." Christians must expect mockery and rejection, because their very lives pose a challenge for others to change. These "others" know our background as sinners and will remain sceptic about the 
changes in our lives after we have accepted Jesus. But: God remains faithful and we must proceed boldly, trusting in God. It should be noted that the analogy with Jesus breaks down at this point because this conversion from a life of sin does not apply to Jesus.

- The Langa Baptist group also used the strategy of finding analogous situations in an interesting, if somewhat conflicting way in their reading of Matthew 13:53-58. If the people of Nazareth rejected Jesus, we have to recognise him for who he is, i.e. the Son of God. We should have faith in Jesus. The analogy (contrast) that the group identified is therefore between the people of Nazareth and themselves. Nevertheless, the group also found analogies between their own experience (as students and young black professionals) and the position that Jesus had as the homeboy who became famous. They therefore not only associated themselves with the people of Nazareth (on the theme of rejection) but also with Jesus himself.

- By contrast (although not exclusively), the Dutch Reformed Church' Ottery group placed themselves in the position of the people of Nazareth. They agreed that: "We are often like those people". They felt that they would probably have rejected Jesus too if they were in the same position. From this the group gathered that one should be willing to witness to Jesus Christ whatever the circumstances may be. They also affirmed the abiding truth that the authority of Jesus as the Son of God should be accepted in faith.

- In their interpretation of Luke 4 the Sokhanya group also employed the interpretative strategy of a prophecy that is being fulfilled. Although explicit links to the contemporary context are not made, their manner of speech shows that they identify with those who are beneficiaries of Jesus' announcement in Luke 4:19, over against those who reject it, as represented by the people of Nazareth.

- The Lighthouse group also employed a promise-fulfilment strategy to appropriate Luke 4 . They acknowledged that a year of grace was proclaimed by Jesus in Luke 4 but had to acknowledge that that they do not always experience such good news in their own lives. The group grappled with this. Some suggested that it takes time in some cases, others that we cannot take grace "for granted". The most popular view was that God's grace has already been given, but that we should claim it. We should search for renewal. The emphasis therefore shifted to human free will and responsibility.

- The Strand Anglican group was given input by the research team that focused specifically on the dimension of application. It mentioned the Jubilee 2000 campaign as one attempt to apply the significance of Luke 4 within the contemporary context of Third World debt. The group responded rather negatively and even angrily to this input. They strongly disagreed with the call for a cancellation of debt. ${ }^{3}$ This seemed to be based on different political views and on the middle class notion that income has to be earned through honest hard work. This response nevertheless tended to confirm the hypothesis as stated above. The group reaffirmed its understanding of the gospel in terms of the

3. Speaker 4, a white male, wanted to know why money had been lent to poor countries in the first place. If it was for food he could accept this, but he was worried that the money had not reach its intended beneficiaries, and later came back to the fact that debts for food were acceptable but not for wars or for the benefit of wealthy members in poor countries. Likewise, Speaker 2, a coloured male, reflected on the fact that during the apartheid period many people asked for handouts for the poor but money did not actually get to the poor since middle persons kept it for themselves. 
soteriological motif of the forgiveness of sins. On that basis they denied any similarity between the Jubilee 2000 campaign and the thrust of Luke 4 .

c) The influence of the specific purpose for which a particular Bible study group usually meets was especially evident from the Bible study events analysed in this research project. In fact, this is perhaps the dominant impression of the research team.

- Of the six groups investigated here only the Sokhanya group is predominantly a Bible study group. As a result, the group members are quite interested to discuss the text and the background of the text.

- Although Bible study and discussion formed the core activity of the Langa Baptist group, it is somewhat difficult to describe the main purpose of this group because of its large size and because the speakers do not always respond to one another but tend to make individual speeches. Perhaps the group meetings here serve as a platform where its youth members may articulate, clarify and test their own beliefs, commitments and values in the presence of others who share their basic faith orientation. This may well be typical of youth Bible study groups.

- The Ottery group is predominantly a support group even though Bible study forms the core activity of the group. They meet to care for one another, to support one another, to pray for those members who are sick, and to encourage one another (e.g. when someone is lonely).

- Since the Strand Anglican group is not a well-established Bible study group it was difficult to assess the main purpose of the group.

- Both the Lighthouse and the Belhar Anglican groups are groups focused on spiritual growth and personal support. Their Bible studies therefore tend to move away from a discussion of the particular text to an affirmation of their existing beliefs, convictions, commitments and values. The discussion of the text thus merely serves as a point of departure in order to discuss matters of faith, spirituality and personal problems. At the end of each session Bible study makes way for "sharing", quoting favourite verses or sayings, discussing personal problems, and so on. It is therefore somewhat unfair to judge their mode of interpretation of the Bible on the basis of this.

These observations prompted the research team to raise the question as to whether the reading strategies of the various groups can really be compared with one another if the purpose of the group meetings differs that much between the groups (even though they were all well established Bible study groups, with the exception o the Strand Anglican group) ${ }^{4}$ All the evidence indicates that a group's composition, purpose and the expectations of the group members play a crucial role in their reading of the text. This is why the Bible will be read in a very different way by established Bible study groups (especially where these groups form part of local Christian communities) compared to groups that function in an academic context or groups that are formed in the context of civil society. The difference between established Bible study groups and groups that are formed on an ad hoc basis (e.g. for the purposes of research experiments) should also be noted. An ad hoc group will read the Bible in terms of the way in which the group perceives the reason why the group was formed in the first place. This can be vividly illustrated from the Bible studies of the somewhat dysfunctional Strand group (that functioned in this sense as a helpful control group). This group repeatedly wondered what the research team expected

4. See the contribution of Conradie on the influence of group dynamics on Bible study elsewhere in this volume. 
from them. They tried to comply with these expectations even though they were explicitly suspicious about the agenda of the research team (aggravated by the input on the Jubilee 2000 campaigned). By contrast, the other groups showed some resilience in "reading the Bible in the way they normally do" and were less interrupted by the presence of the video camera. This leads to the conclusion that the group's purpose plays a very significant role in group Bible study and that the influence of other factors, including the broader social context, have to be understood in this light.

\subsection{The role of the text itself}

The following hypothesis was stated on this aspect in the research proposal:

Features in the surface structure of the text are predominantly interpreted in terms of the dominant heuristic keys of the group and not within the parameters of the text itself. The actual reading of the text therefore serves to reinforce, clarify, elucidate and refine the existing beliefs, values and practices of the group. Groups tend to avoid the unfamiliar, the problematic, the contradictory, the ambiguous, any signs of "otherness" or particularity. As a result, many interpretations of a text appear highly generalised. Particular texts are merely regarded as examples of well-known types. In this way, the expectations of the group are almost always confirmed.

The Sokhanya group is the one group that did not conform to this hypothesis. They showed a persistent willingness to engage with the text and with various features in the surface structure of the text. The reading strategy that they favoured is one where unclear aspects in the text are illuminated through quotations from other canonical texts. This also served the purpose of exploring new connotations, hitherto unnoticed aspects of the meaning of the text. This willingness to learn is perhaps understandable since this group functions within the context of a Bible school. Nevertheless, it is quite significant given the low educational qualifications of the members of this group (if compared to all the other groups in this study).

The other groups did not show a particular willingness to engage with the detail of the textual evidence even though they did focus on and discuss aspects of the text. The attempt to read the text as text often had to make way for a reinforcement of the dominant doctrinal keys of the group. In some cases the text only provided a point of departure for a topical discussion. This was particularly evident in the Luke 4 reading by the Langa Baptist group where the leader directed the discussion from the outset to the theme of a culture of indebtedness.

The Ottery group formed an interesting example of the interplay between the text, the doctrinal keys of the group and the purpose of the group. The perceived focus of this group's activities is indeed the study of the Bible. Through the leadership of the local pastor the group paid attention to various aspects of the text such the literary context. For the second Bible study (on Luke 4) this group was given some input that required them to do a close reading of the text. They had to compare Luke's and Matthew's versions of the incident where Jesus was rejected by the people of Nazareth. They were clearly at a loss with this task. They complained that this Bible study was "a bit too difficult". They did not find the differences between these two texts interesting or problematic ("Whose version of the story reflects what really happened?"). In the end they tried to assimilate what they did not grasp in terms of what they were familiar with. This clearly allowed for a reinforcement of the group's existing doctrinal keys. 


\subsection{The role of the historical context}

The following hypothesis was stated on this aspect in the research proposal:

Bible Study groups are often less interested in historical questions about "what the text has meant" (and thus the historical background of the text) and more in "what the text means" within their own context. There is a tendency to assimilate the "world" of the Bible (its narratives, characters, topography, symbols, themes, etc) within the group's own interpretative world. The larger frame within which a text is interpreted is usually not historical but doctrinal or moral (laws, principles). Often, the text is simply regarded as another example of Christian life.

Most Bible study groups are aware that some historical background is necessary for adequate Bible study. They would normally find such background information "interesting". However, since the main purpose of most Bible study groups is not related to a growth in their knowledge of the Bible, such groups tend not to linger on the world behind the text for too long. There is indeed a tendency to assimilate the "world" of the Bible within the group's own interpretative world.

Nevertheless, the Langa and especially the Sokhanya group showed some hermeneutical competence in this regard, most notably in their approach to Matthew 13. Members of the Langa group used their personal experiences to reconstruct the Sitz-im-Leben of the text. Maybe Jesus was rejected because he returned to his hometown with a new reputation (e.g. education qualifications) while the locals thought of him as the carpenter's son. The Sokhanya group focused on the socio-psychological reasons for the rejection of Jesus in Nazareth and used their knowledge of the internal dynamics in small rural towns to offer a plausible explanation for the events (people do not expect someone from their own village to be a prophet). They felt some natural affinity with the situation described in the text since most of them have grown up in similar close-knit communities to which they go back from time to time. The Lighthouse group also tried to understand the reasons for the rejection of Jesus in terms of the socio-cultural background of the text. They came up with a number of possible answers. The answer to which the group returned most often is that Jesus was simply too familiar - too "common" as one said. The reputation of this Nazareth resident did not make sense to the local audience, because they knew his background all too well. Some members provided parallels from their own experience. Others added that Jesus' social class or place of origin (ghetto) may have played a role in this regard.

The Sokhanya group was also provided with some input on the historical background of Luke 4 (e.g. on the year of grace and the reference to Leviticus 25:8-28). This input did not have a significant impact on the reading of the group In fact, the input was conspicuously ignored during the discussion, although it probably helped them to understand what "the acceptable year of the Lord" meant. When one member (correctly) interpreted "carpenter" as "middle class, not upper class" and another (wrongly) compared Nazareth to Crossroads or a ghetto, it became clear that the group is both willing and able to use what knowledge they have or think they have.

\subsection{The role of the contemporary context}

The following hypothesis was stated on this aspect in the research proposal:

Contextual factors such as race, class, gender, age, geography do play a role in the dimension of application in Biblical interpretation but only on the basis of the dominant doctrinal keys of the group. The choice of doctrinal keys is largely influenced by the ecclesial tradition of the group members. 
The data from the 12 Bible study events tended to confirm this hypothesis. The possible influence of contextual factors is filtered through the lens of the doctrinal keys of the group's ecclesial tradition. In all the Bible study events there were some references to the local context within which a particular group is situated. This does not necessarily imply that the particular context influenced or determined (consciously or sub-consciously) the way in which the Bible is read. In some cases the context merely serves as the locus within which the truths (re)discovered through the Bible study had to be applied (deliberately). It is therefore necessary to distinguish between various ways in which the contemporary context plays a role in group Bible study.

Nevertheless, the influence of contextual factors should not be underestimated.

- In the Matthew 13 reading by Langa Baptist group there is an interesting interplay between contextual and confessional factors. The group argued that, if the people of Nazareth rejected Jesus, we have to recognise him for who he is, i.e. the Son of God (assuming a Nicene Christology). We should have faith in Jesus. Nevertheless, the group also found analogies between their own experience (as young black professionals) and the position that Jesus had as the homeboy who became famous. They therefore did not only associate themselves with the people of Nazareth (on the theme of rejection) but also with Jesus himself.

- The clearest example of a contextual reading of the Bible was the Langa Baptist group's discussion on Luke 4. This group was given some input on the contemporary problem of indebtedness (with reference to the Jubilee motif) that presumably helped to focus their attention on the role of the contemporary context. They discussed many interesting examples of indebtedness derived from their own experience. The text merely served as a loose point of departure for a thematic discussion. It is interesting to note that (against the thrust of Luke 4) the comments from several of the speakers did not follow the theme of liberation but that of financial responsibility. This was clearly influenced by the (hope for) increasing affluence of several members of this group consisting of students and young black professionals. It is a pity that the group did not explore the theme of Third World debt at all since their views on this issue may have been quite interesting. The international context did not attract as much attention as the local context did.

- The reading of Luke 4 by the Dutch Reformed Church' Ottery group is also interesting in this regard. Although the Dutch Reformed Church traditionally occupied a position of power in the South African society, the group members experience themselves as relatively powerless. They are elderly women living in a lower middle class neighbourhood with a strong Muslim presence. They are exposed to various forces that are beyond their locus of control but that may well influence them and their children. They therefore find comfort in the abiding truths of the gospel and are responsive to the message that Jesus came for ordinary poor people and not for the rich and powerful.

- Danie van Zyl's comments on the way in which the text is assimilated in the contemporary context (or does the opposite actually apply?) by the Sokhanya group is also significant. Van Zyl points out that the fact that no explicit references to the contemporary context were made may be due to the fact that in African churches preaching very often deal with the "Biblical scenario" only. There is nevertheless a level of identification with the reality of which the text speaks, because the speakers are 
not really conscious of the historical gap between "then" and "now". It is assumed that the text speaks of a "present" reality, with which they can identify. ${ }^{5}$

- In his discussion of the Lighthouse group, Douglas Lawrie argues that the lower-middle class background of this group plays a significant, if sub-conscious role in their reading of Luke 4 (especially). The group avoided a literal interpretation of Luke 4:19 (with themes such as the gospel to the poor, healing for the downtrodden, sight for the blind, freedom for prisoners, a year of grace). It may be assumed, given the group's Pentecostal background, that the concrete reality of healing miracles would not be regarded as problematic. Nevertheless, this group (more than some of the others) deliberately spiritualised the meaning of the text. The Jubilee symbolises a new beginning and comes about through salvation from sin. Therefore: Each day with God is Jubilee.

Lawrie suggests that this may be born from a realisation that socio-economic realities cannot be transformed easily. With a sense of realism, the group members do not wish to raise false expectations in this regard and have developed mechanisms to cope with the demands of life in their own context(s) in a more or less satisfactory way. The group therefore adopted a promise-fulfilment strategy to interpret the text. The group already experience something of the year of grace but in a spiritual sense: their faith in Jesus has helped them to find a new orientation in life. This helps them to avoid falling back into the sub-cultures (the traps of drunkenness, promiscuity, gangsterism, drug-abuse, gambling, witchcraft) that surround them. In this indirect way the spiritualised understanding of the year of grace does yields some material benefits, but not necessarily through dramatic or revolutionary means. A futurist understanding of the Jubilee is balanced with a realised eschatology that harbours hints of a prosperity gospel.

\subsection{The impact of ideological distortions}

The following hypothesis was stated on this aspect in the research proposal:

Bible study groups, not surprisingly, remain largely unaware of a range of possible ideological distortions in their reconstructions of the text, their own traditions, their interpretative "world", and the broader contexts within which they live.

This hypothesis is difficult to assess on the basis of the video recordings of the various Bible study events only. A more detailed study of each group would be necessary to determine ideological distortions that may be present in each group's approach to Biblical interpretation.

For the second Bible study on Luke 4, the Belhar Anglican group was provided with some input on the translation of the verb thaumazo in Luke 4:22. It may be translated as "being amazed" or as "being shocked and upset". The intention of this input was to help the group to question their English translations of this text and their own dominant understanding of this text. This input did not succeed in raising an ideology-critical awareness. The group did not respond to the input directly. It only led to a few comments and some loose associations with the theme of anger. In this case the input itself proved to be inadequate and did not facilitate the testing of this research hypothesis.

5. See also West's notion of re-membering as one important reading strategy used by African Christians. See West, GO 1999. Reading other-wise: Re-envisioning the reading practices and place of the socially engaged biblical scholar. Scriptura 68, 49-66. 


\subsection{The role of group interaction}

The following hypothesis was stated on this aspect in the research proposal:

The interaction among group members is often aimed at reinforcing, clarifying and elucidating the beliefs, practices and purposes of the group. The categories of insiders (insiders within and outsiders within) and outsiders (insiders outside and outsiders outside) may be helpful to analyse this interaction. Some insiders may also become discontented with the dominant tendency for confirmation of existing beliefs, especially if their expectations include a strong element of growth.

The group dynamics, the interaction between group members and the leadership styles of the group leaders varied between the six groups that were analysed.

- The local pastor acts as the leader of the Ottery group. There is a clear educational and age distinction between the group leader and the rest of the group of whom only a few really participated in the discussions. The contributions from the pastor, perhaps against his own intentions, did tend to reinforce, clarify and elucidate the prevailing beliefs of the group. In this particular group this served as a comfort to group members who experience themselves as relatively powerless in a challenging environment.

- The Sokhanya group usually elects a group leader for each Bible study session. The leadership style of the person elected for the two Bible studies that were analysed in this project seems to encourage participation by the members of the group. This stimulated an exploratory approach to the Biblical text. The purpose of the group is to study the Bible and not primarily to reinforce the beliefs of the group.

- The seating arrangement of the Langa group tended to encourage individualist participation by group members who had to get up in order to address the group. The group provided each member with a "stage" to share his or her views on religion, values, commitments and priorities. Although the leader tried to bring the group back to the particular theme that he wished them to focus on, the vibrant discussion in the group made this rather difficult. One may argue that the group tended to dominate the group leader since they did allow his agenda to determine the discussion.

- The leader of the Lighthouse group clearly dominated the group interaction and this allowed him to engage in lengthy speeches. These speeches had a strong doctrinal orientation. They fervently reinforced the beliefs and values of the group leader. Nevertheless, the group members were quite willing to tolerate the dominance of the group leader. There was a sense of mutual support and an honest eagerness to interpret and apply the Bible. The solidarity within the group seemed to help the group members to face the challenges that they experience in the world outside the group.

- The Bible studies of the Belhar Anglican group was characterised by lively interaction even though the youth members of the group seemed to be somewhat shy to participate.

- The group dynamics of the Strand Anglican group was dominated by long and uncomfortable periods of silence and limited interaction. In his description of the group dynamics Wananaker notes that the group was recently formed, that the group leader was absent (overseas), that they lacked leadership skills as a result and that they usually relied on the assistance of a guide book for their Bible studies. The group was therefore somewhat dysfunctional.

The impact of group dynamics on group Bible studies is clearly highly complex. The evidence from this research project is somewhat ambiguous. More research and a larger 
sample would be necessary to understand the interaction within Bible study groups and the way in which this influences the Bible studies.

One may nevertheless conclude that the evidence from this research project supported this hypothesis in some cases. The need for group cohesiveness was evident especially in the Dutch Reformed Church' Ottery, the Belhar Anglican and the Lighthouse groups. In these groups the Bible studies tended to reinforce and clarify the existing beliefs of the groups. It should be noted that all three these groups function basically as spiritual and social support groups. The influence of the purpose of the group and the expectations of the group members should therefore not be underestimated. Where the Bible studies were not conducive to meet these expectations, the discussions were hampered by uncomfortable periods of silence.

\subsection{The dominant thrust of each group's interpretation}

It may be helpful to summarise the way(s) in which each of the groups read and interpreted the two passages from Matthew 13:53-58 and Luke 4:16-22, 28-30. How did each group read the Bible and in what ways did these interpretations differ from one another? Another question would be why these interpretations differed from one another? What role did contextual factors, including race, class, gender, age and ecclesial tradition pay in this regard?

These questions are certainly interesting to entertain but any attempt to answer to these questions adequately would be extremely complex and would have to address a number of difficulties. The following problems may be noted in this regard:

- There is, of course, a danger that one may condense and homogenise the different interpretative strands within each group. A researcher is naturally inclined to rely on the words of the individual speakers. However, this may be misleading because some group members (or leaders) tend to dominate the discussion. Silence from the other group members does not necessarily imply consent. The interaction within any group would be far more complex than a short summary would allow for.

- There remain differences of opinion (also within the research team) on what constitutes an interpretation. Does "interpretation" refer to the way in which the various connotations of the Biblical text are cognitively understood? Or to an assessment of the meaning of the text within its "original" context(s)? Or to more or less deliberate and conscious attempts to formulate the implications of the text for a particular context verbally (the aspect of application)? Or to the praxeological impact of the text on the group and in the lives of the group members - which may well differ from the way in which the group formulated the meaning of the text verbally.

- Any attempt to offer a causal explanation for the different interpretations of the various groups would be incredibly complex, since there may a number of other hidden factors that may well influence the group's views. One of these factors may be the impact of the research activity itself and the presence of the video cameras. To isolate any particular factor that influence Biblical interpretation would not do justice to highly complex nature of this event.

During the pilot phase of the project the research team decided not to formulate any empirical conclusions regarding the different interpretations of the 8 groups that participated in the pilot project. Likewise, the purpose of the second phase of the project was not to compare the different readings with one another or to offer causal explanations in this regard. Instead, the research team investigated a number of 
hypotheses relating to the various factors that may play a role in Biblical interpretation (see the discussion above). Nevertheless, there is no doubt that the various Bible study groups that participated in the project would be curious to know how their interpretations of the Bible differed from those of the other groups.

We therefore offer, somewhat reluctantly, a brief summary of the various interpretations by the 6 Bible study groups that participated in the second phase of the project. "Interpretation" is regarded here as the way in which a particular group integrated for themselves all seven the factors that were identified and discussed above. The aspect of application form the crucial ingredient in this regard since it requires an attempt to establish a link between the Biblical text and the contemporary context.

\subsection{The 6 interpretations of Matthew 13:53-58}

a) The Sokhanya group were interested in the person of Jesus as an example of Christian leadership. As religious leaders, they experience similar suspicion and rejection from their local communities and families who know them and who tend not to expect anything special of them. If Jesus showed strength of character to respond to such a situation this may give them the power as Christian leaders to confront similar situations.

b) The Ottery Dutch Reformed Church' group focused on the theme of faith in Jesus. We should not reject Jesus. Instead, we should simply believe in Jesus without requiring him to miracles in our lives. We should be witnesses to Jesus, despite the opposition that we may encounter. Unlike the people of Nazareth we should not evaluate someone on the basis of external appearances. This observation may also have ethical implications in the way that we treat others.

c) The Langa Baptist group also focused on the theme of faith in Jesus. We should maintain faith in Jesus. If the people of Nazareth rejected Jesus we should not. At the same time we may experience, like Jesus, moments of rejection by others in our local community (e.g. when they do not accept our educational and professional credentials).

d) The Strand Anglican group suggested that the reason why Jesus was unable to perform miracles in his hometown had to do with the lack of trust and faith in him. The people of Nazareth did not recognise his divine origins that gave him exceptional wisdom and the ability to do miracles. Just as the people in Nazareth did not trust Jesus, we are often unable to hand over our own problems and to trust that Jesus can solve them.

e) The Belhar Anglican group experienced similarities between their own situation and the situation in which Jesus found himself. Their life experience of not being respected by their own families or within their immediate context(s) resonates with the lack of recognition which Jesus experienced in his hometown. If Jesus was criticised as a prophet by his own people, Christian leaders today also suffer from lack of respect and recognition within their own congregations.

f) The Lighthouse group regarded the life of Jesus as an example of what Christians may expect to experience. The people of Nazareth took offence at Jesus, because they knew him as an ordinary member of the community and could not accept him in a new role. Similarly, we are changed when we accept Jesus, therefore we give offence to those who know our background and had known us as sinners. What Jesus suffered, we shall also suffer: "There will be 'offence' in your life." The example of Jesus both consoles and encourages Christians who experience mockery in a fairly hostile environment. 


\subsection{The 6 interpretations of Luke 4:16-22, 28-30}

a) The Sokhanya group regarded Jesus as the fulfilment of Isaiah's prophecy. By saying that the Spirit of the Lord is upon me Jesus wanted people to recognise who he really was, i.e. the Son of God. It is when one discovers, through the Holy Spirit, who Jesus is that this year of release for the blind, the imprisoned, and the enslaved takes effect. The themes in the text that were not immediately relevant to the group were often spiritualised. This allowed for a re-contextualisation of the text. One speaker suggested that: "We experience the release when we as believers are no longer addicted to liquor."

b) The Ottery group appreciated the message of Luke 4 that Jesus came to attend to the needs of the poor and powerless. They gathered from this that they should also grant others (including their Muslim neighbours) opportunities in life. If the text is about God's great love for us as sinners, we should treat other with compassion too.

c) The Langa Baptist group focused on the theme of indebtedness, following the input by the research team. Although Luke 4 speaks of a year of grace (i.e. when debts will be cancelled), the group emphasised that a culture of indebtedness can be prevented through personal financial discipline. This is only possible if we live a life of faith in Jesus.

d) The Strand Anglican group focused on the year of grace in Luke 4:18-19. They regarded blindness and poverty as a spiritual and moral problem that has to be addressed. When prompted to consider the Jubilee 2000 campaign as a response to this text, the group emphasised the need for financial responsibility instead of a blanket cancellation of debts.

e) The Belhar Anglican group focused on the theme of being fulfilled with the Spirit. This enabled Jesus to perform such miracles (healing the sick, a recovery of sight to the blind). As the Spirit enabled Jesus, so will He enable us to do wonders today. However, blindness is not only a physical and medical predicament. Blindness is also the result of a lack of ethical and theological insight caused by a lack of faith. If we have faith in God we will receive what we have asked for.

f) The Lighthouse group rejected the emphasis in liberation theology on social, economic and political liberation from oppression and poverty. Instead, they understood Luke 4:19 as a form of spiritual liberation. God's grace becomes evident in our lives when we are liberated from sin and from the devil's claws. What is required is faith in Jesus that will provide Christian with a new life orientation and that will help them to cope with the demands of life. In this way the spiritualization of the text allows for a recontextualisation of the motif of liberation, albeit in a highly privatised context.

These interpretations of Luke 4 may (for some) be somewhat surprising in a country where liberation theology has had considerable influence and given that at least four of the groups come from previously disadvantaged contexts. None of the groups were really interested in the implications of the text for the South African and international political economy. Instead, the groups offered a thoroughly religious and sometimes highly spiritualised reading of the text. If Jesus came to establish an era of grace, this can only be appropriated through a life of faith in Jesus. This implies that the divine authority of Jesus has to be recognised. By contrast, the people of Nazareth rejected Jesus as a prophet (not as a political agitator). In terms of a promise-fulfilment interpretative strategy, those who believe in Jesus may eventually experience the material benefits that Jesus referred to. 


\section{Reflections on the significance of the research project}

When the research team discussed the aims of the research project in 1996 it focused on the notion of interpretative strategies. How do established Bible study groups read the Bible? How do they relate the Biblical texts to their own contexts? The term "strategies" that was used in this regard suggests that it may be possible to discern and describe various ways of approaching this task. Although the military roots of the term "strategy" suggest a certain calculated and cunning precision and a set sequence of steps that may be followed to acquire an external goal, this clearly does not apply to such interpretative strategies.

In the pilot project it soon became evident that interpretation is an incredibly complex process. The paradox here is that Bible study groups find it relatively easy to discuss a text and to reflect on its significance for their context(s). In this sense interpretation is not difficult at all. In fact, we interpret the Bible spontaneously every time that we read it directly or indirectly, consciously or sub-consciously, for better and often also for worse. However, any detailed description of the interpretation event proves to be complex and elusive. This is analogous to attempts to define or describe the notions of love, wisdom or hope.

As a result, the notion of interpretative strategies remained somewhat vague during the initial phases of the project. Instead, some more general questions were raised. What happens when Bible study groups read the Bible? How can such events best be modelled or described? These questions clearly required both empirical research and theoretical clarification. The following three components were therefore identified in the project design for the pilot project:

- A theoretical component that reflects on the modelling of Biblical interpretation;

- An empirical component that investigates the interpretation of the Bible within different reading/reader communities;

- An operational component that could develop a pedagogical instrument to facilitate adequacy in the context of group Bible study and that could design programmes for church leaders to sensitise them about the way reader communities interpret the Bible.

Although the pilot project engaged in extensive empirical research it remained exploratory in orientation. It soon became clear that the pilot project would not lead to any empirical conclusions. At best, the empirical observations aided the task of theoretical clarification. As a result, the empirical and operational (or pedagogical) components of the project stayed underdeveloped.

Although such theoretical clarifications remained contested, also within the research team, the second phase of the project endeavoured to test a number of hypotheses empirically. The outcome of this process was described above. It is quite clear that these results remain fragmentary and provisional. A similar study on other Bible study groups may yield different results. A much larger empirical project with more detailed descriptions may be necessary to reach some clarity on the status of the hypotheses as stated above. The experience derived from the pilot and second phases of the project indicates that such a project would be arduous and labour intensive. This volume of essays therefore has to suffice to document the provisional results of the theoretical and empirical components of the project.

A few further observations on the operational or pedagogical components of the project are necessary. As indicated above, it was envisaged during the pilot project that the theoretical work would enable the research team to develop a "pedagogical instrument" that will be of some use for Bible study groups. More specifically, this pedagogical instrument would be based on the criteria for relative adequacy in Biblical interpretation - as described 
by Conradie and Jonker elsewhere in this volume. In other words, the idea was to simplify the list of criteria in order to provide a kind of "checklist" for adequate Bible study to Bible study groups. Did you take the historical context, the literary context, the genre, and the structure of the Biblical text into account? How does your Bible study help to foster your tradition of interpretation? Did you take the contemporary context within which you live into account? Did you watch out for ideological distortions? These questions therefore assume the hermeneutical analysis of various factors that play a role in Biblical interpretation.

During the second phase of the project the desirability of such a pedagogical instrument was fiercely debated. This debate was the unintended result of the research procedures that were followed during the second phase of the project. As indicated above, we (Conradie \& Jonker) formulated a number of hypotheses on the factors that play a role in Biblical interpretation. The purpose of these hypotheses was not to try to establish whether these factors play a role, but to articulate in what way they influence group Bible study and how they do so in relation to one another. In order to test these hypotheses each group was given a specific input related to one of the aspects of Biblical interpretation as identified and described in the hypotheses. The purpose of these inputs was not in the first place to assist the particular Bible study group with their Bible study. The purpose was to ensure that the role of one aspect of Biblical interpretation would be highlighted during the Bible study event. This would then allow the research team to establish in what way this specific aspect plays a role in Biblical interpretation within the context of established Bible study groups.

We (Conradie \& Jonker) formulated the specific content of the various inputs in consultation with the rest of the research team before the various Bible study meetings were organised. We then decided which input would be given to which Bible study group. This was done somewhat arbitrarily and was influenced by the withdrawal of some of the groups that participated in the pilot project. If anything, the groups received inputs that corresponded to the perceived weakness of a particular group. ${ }^{6}$ In a letter inviting the groups to participate in the project the groups were informed that they will receive such input for the Bible study on Luke 4 and that the research team would like to find out how the input helped and influenced their reading of the text. The inputs were given to the group leaders by the research assistants in a written form (just) before their Bible studies on Luke 4. The group leaders were informed that they could use these inputs in whatever way they wished to. In some cases the text was passed to group members who wished to see it (the Strand Anglican group), in some cases the input was read to the whole group at the start of the meeting (the Sokhanya and Langa Baptist groups) while the group leaders used and integrated the input during the course of the discussion (the Dutch Reformed Church' Ottery, the Lighthouse and the Belhar Anglican groups). In hindsight, it may have been necessary to be more prescriptive about the way in which such inputs should be used.

The purpose of these inputs was therefore not in the first place educational but experimental. Nevertheless, the impact of these inputs on the discussion in the various groups raised a number of important questions. In most cases, it was quite clear that the

6. This may provide a partial explanation for the inability of some of the groups, e.g. the Dutch Reformed Church' Ottery group (comparing Luke's and Matthew's versions of the narrative) and the Belhar Anglican group (on a critical reading of the text in general and the translation of thaumazo specifically) to integrate the inputs in their discussions. In the case of the Strand Anglican group (on the Jubilee 2000 campaign) and the Lighthouse group (on liberation theology) the particular content of the input led to some resistance. The Sokhanya group largely ignored the input while the theme of indebtedness (the role of the contemporary context) resonated very well with the Langa Baptist group. Also compare the discussion below. 
groups experienced these inputs to be more of a hindrance than an aid to Bible study. The impact of these inputs on the various groups may be summarised in the following way:

- The input that the Ottery group received required from them to compare Matthew 13 and Luke 4 with one another (both texts tell the story of Jesus being rejected in Nazareth). The group did not find the differences between these two narratives either problematic or stimulating. As a result the discussion did not really flow. They were unable to ask literary questions about the two texts and found the questions posed by the group leader "difficult". Since this group is primarily a support group, the group members are more interested in a re-affirmation of their faith than in dealing with theological or exegetical problems.

- The Sokhanya group simply noted the input on the historical background of the Jubilee motif. They did focus on Luke 4:19 as a result although the input had little if any impact on their actual reading of the text. They did not regard the input as providing historical background. Since cross-referencing is a typical feature of this group's interpretative culture, this simply offered an additional textual reference to understand Luke 4:19.

- The Langa group received some input on the contemporary context (the problem of indebtedness). This input was well received by the group. In fact, it influenced the discussion too much since the group did not really discuss Luke 4 but focused on the problem of indebtedness instead. The group members were able to assimilate the input quite easily within their social context since it was regarded as existentially relevant. The input therefore worked perhaps too well.

- The input that was provided to the Strand group focused on the aspect of application (the Jubilee 200 campaign as one contemporary appropriation of the Luke 4:19). There can be no doubt that the input rather than helping them proved an obstacle to interpretation since they, like so many students, tried to work out what they were supposed to answer. The group members were also angered by the specific content of the input (the cancellation of Third World debt) and showed some political resistance in this regard. Nevertheless, one may also argue that the input at least elicited a response from the group on the aspect of application, albeit a negative one. This led the group to emphasise the need for financial responsibility and to spiritualise the meaning of Luke 4:19.

- The Belhar Anglican group received input on the translation of Luke 4:22. The intention of the input was to help the group members to question the dominant translation of the Greek thaumazo in this verse (to be amazed or to be shocked). This had to stimulate a critical reading of the text and suspicion about existing interpretations of the text. They had to wonder whether we could trust the translations that we use. This input had little if any impact on the group discussion. The group focused on the notion of "guidance by the Spirit" and the association with the text remained rather superficial. Perhaps the input itself was inadequate in this case. The main purpose of the group is to support one another and not to encourage a critical reading of the Bible.

- The input that was provided to the Lighthouse group focused on the history of interpretation of Luke 4:19 and more specifically on the way in which this text is understood in liberation theology. The group and especially the group leader clearly expressed a negative attitude to such a reading of the text. This stimulated the group to reaffirm its own identity and to juxtapose their reading of the text over and against that of liberation theology. One may argue that this negative response at least heightened the group's awareness of their own spirituality. 
It should be stressed once again that the purpose of these inputs was not to "help" the Bible study groups in any way. The aim was not to establish whether these inputs would be conducive to a relatively adequate interpretation of the text. The question was not whether the groups would experience the inputs to be useful. The purpose of the inputs remained primarily experimental. Indeed, negative responses to the inputs may be quite helpful to test research hypotheses. Even where the inputs were (purposefully?) ignored this may stimulate some critical reflection.

Nevertheless, in most cases the inputs "fell into a dark empty hole" - as one member of the research team expressed his sense of disillusionment. This raised a number of important questions. What kind of contribution(s), if any, can trained readers make to facilitate group Bible study? In what ways and in which format should these inputs be made available to established Bible study groups? How does one respect the integrity and identity of a group, prevent a dependency on outside expertise (which far too many popular Bible study guides do not avoid), stimulate a self-critical mode of reading the Bible and contribute to relative adequacy in Biblical interpretation?

The research team reached more or less consensus on the following conditions for the inputs of trained readers to be fruitfully integrated in the context of group Bible study:

- Hermeneutical analysis does not necessarily contribute to more adequate Biblical interpretation. The critical tools that are required to analyse various aspects of Biblical interpretation are not particularly helpful for Bible study groups. Hermeneutics as the theoretical reflection of interpretation events is far too abstract to aid concrete Bible study.

- Inputs from trained readers are only appropriated where a relationship of trust and respect exists between the group and the trained reader exists. This is, for example, possible where the trained reader is a normal member of the group, where the trained reader is the local pastor with whom the group has regular contact in another context, or where the trained reader is a well-respected author. The availability of information will not necessarily be sufficient by itself. Such information will not be appropriated if there is a lack of communication or trust. The information provided by the trained reader cannot be separated from her or his personal integrity as perceived by the group. Such personal integrity is of particular importance where there are significant differences between the group and the trained reader in terms of education, class, gender, race or age.

- The way in which inputs are communicated to and received by the group is also crucial. Bible study groups do find background information, especially relating to the historical background and the literary structure of the text helpful. Such background information has to be communicated clearly and put into context.

- Any ad hoc inputs by trained readers within particular Bible study events will not necessarily be assimilated by a Bible study group. The availability of potentially valuable information does not enhance Biblical interpretation by itself. The appropriation of inputs from trained readers is only possible where a group has developed a certain hermeneutical competence over a period of time. A group who has, for example, developed a sensitivity for literary genre will be able to integrate any literary inputs much easier. This requires guidance over a period that is long enough to acquire such skills.

From these observations it seems clear that further reflection on the interaction between trained readers and established Bible study groups may be required. This will require not only theoretical but also empirical research on the various ways in which trained and ordinary readers of the Bible relate to one another. 